\title{
Mate Intake and Risk of Breast Cancer in Uruguay: a Case- Control Study
}

\author{
Alvaro L Ronco ${ }^{1,2,3}$, Eduardo De Stefani ${ }^{4}$, Beatriz Mendoza ${ }^{5}$, Hugo Deneo- \\ Pellegrini $^{4}$, Alvaro Vazquez ${ }^{3}$, Estela Abbona ${ }^{6}$
}

\begin{abstract}
Regarding 'maté' intake (infusion of Ilex paraguariensis herb, a staple beverage in temperate South American regions), most epidemiologic studies showed positive associations with risk of some cancers, (e.g. upper aerodigestive tract), but evidence on breast cancer (BC) risk is limited to a previous multi-site study, which

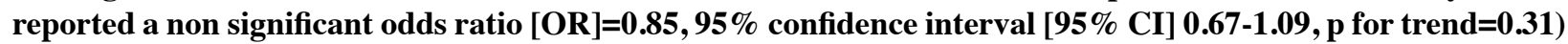
for the highest quartile of intake. The present study was conducted in order to further assess associations of 'mate' intake with $\mathrm{BC}$ risk. We combined two databases of women belonging to public and private healthcare hospitals. The sample included $572 \mathrm{BC}$ incident cases and 889 controls interviewed with a specific questionnaire featured by socio-demographic, reproductive and lifestyle variables, and a food frequency questionnaire of 64 items, also analyzing 'mate' intake (consumer status, daily intake, age at start, age at quit, duration of habit, intensity of intake). ORs and their $95 \% \mathrm{CI}$ were calculated through unconditional logistic regression, adjusting for relevant potential confounders. The highest quartile of 'mate' intake was inversely associated with $\mathrm{BC}$ risk $(\mathrm{OR}=0.40,95 \% \mathrm{CI}$ 0.26-0.57, $\mathrm{p}$ for trend $<0.001)$. Stratified analyses also displayed strong significant inverse associations for ' $m$ ate' in frequent tea drinkers $(\mathrm{OR}=0.22)$, high energy intake $(\mathrm{OR}=\mathbf{0 . 2 3})$, high body mass index $(\mathrm{OR}=0.29)$ and in postmenopausal women $(\mathrm{OR}=0.36)$, among other results. As conclusions, we found evidence of a significant inverse association for 'mate' intake and $\mathrm{BC}$ risk.
\end{abstract}

Keywords: Breast cancer - Ilex paraguariensis - mate - tea - coffee - infusions.

Asian Pac J Cancer Prev, 17 (3), 1453-1461

\section{Introduction}

Breast cancer $(\mathrm{BC})$ is the leading malignancy among Uruguayan women, with a national age-adjusted incidence rate of 73.1 per 100.000 (Barrios et al., 2014), the highest one among South American registries (Ferlay et al., 2013). Furthermore, the capital city Montevideo showed in the past decade the highest incidence rate of the World (Parkin et al., 2002). Theoretically, this could be the outcome of unusually high prevalence of risk factors and a low prevalence of protective factors combined.

Several studies conducted in Uruguay have thoroughly analyzed the relationship between nutrition and BC (Ronco et al., 2010a; Ronco and De Stefani 2012; 2013a), from diet (De Stefani et al., 1997a,b; 1998a; Ronco et al., $1996 ; 1999 ; 2006 ; 2010 b)$ as well as from anthropometry (Ronco et al., 2008; 2009; 2013b). Besides, international literature about hot drinks and BC is still inconsistent concerning possible associations (Gierach et al., 2012; Jiang et al., 2013; Wu et al., 2013; Gao et al., 2013; Nie et al., 2014; Bhoo-Pathy et al., 2015). On the other hand, local studies about 'mate' (a hot infusion made from the herb ilex paraguariensis, which is a staple nonalcoholic beverage in temperate South America) and its role on cancer were mainly focused on the upper aerodigestive sites (Vassallo et al., 1985; De Stefani et al., 1988; 1990; Castellague et al., 2000; Sewram et al., 2003; Ronco et al., 2004; Deneo-Pellegrini et al., 2013; Lubin et al., 2014), usually showing positive associations with these tumors.

Recently, our group published a multi-site case-control study focused on 'mate' drinking and the risk of several cancers in population admitted to the public hospitals healthcare system, which showed a non significant negative association for high 'mate' intake and $\mathrm{BC}$ risk $(\mathrm{OR}=0.85,95 \%$ CI $0.67-1.09, \mathrm{p}$ for trend=0.31) $(\mathrm{De}$ Stefani et al., 2011a). It was the first time that findings on this topic were reported.

In our opinion, the evidence linking intake of this hot infusion and BC is not enough, and in addition, the applied regression model did not take into account relevant variables to this cancer site, such as menstrualreproductive history, body mass index and family history

${ }^{1}$ Unit of Oncology and Radiotherapy, Pereira Rossell Women's Hospital, ${ }^{3}$ Biomedical Sciences Center, University of Montevideo, ${ }^{4}$ Pathology Department, Clinical Hospital, UDELAR State University, ${ }^{5}$ Endocrinology and Metabolism Department, Clinical Hospital, UDELAR State University, ${ }^{6}$ Nutrition Department, Pereira Rossell Women's Hospital, Montevideo, ${ }^{2}$ School of Medicine, IUCLAEH, Maldonado,Uruguay*For correspondence: alv.ronco58@gmail.com 
of BC. Considering that Uruguayans are the World's highest 'mate' consumers $(9-10 \mathrm{~kg} /$ person/year of the herb and ca. 400 liters/person/year of infusion) (Comision Honoraria de Lucha Contra el Cancer, 1993), we believe that research on the proposed subject is scientifically rewarding. In order to clarify some of these aspects and using a detailed multi-topic questionnaire applied to a sample which includes women from both healthcare systems, we have conducted the present study.

\section{Materials and Methods}

Two case-control studies on BC were conducted in Montevideo (where $45 \%$ of inhabitants live) by our group: one of them was carried out during 1996-2004 in the major public hospitals (Oncology, Clinicas, Pasteur, Maciel) and the other one was performed in a private hospital (IMPASA, abbreviated name of former Instituto Medico de Prevision, Asistencia y Servicios Afines) in the years 1999-2001. The respective databases, having the same basic structure, allowed us to analyze in the present study a total sample of 1461 participants, 572 cases and 889 controls. We will briefly describe the selection criteria regarding participants from each healthcare system.

\section{Public hospitals}

During the study period a total number of 480 newly diagnosed and microscopically confirmed BC were considered eligible for the study. A number of 19 patients refused the interview, leaving a final total of 461 cases which were included in the study (response rate 96.0 $\%)$. In the same time period and in the same hospitals, 685 hospitalized patients having diseases not related with smoking, drinking and without recent changes in their diet were considered eligible for this study. Patients proceeded from any part of the country, even from rural areas. Of them, 18 patients refused the interview, leaving a final total of 667 controls (response rate $97.4 \%$ ). Four

Table 1. Distribution of Cases and Controls

\begin{tabular}{|c|c|c|c|c|c|}
\hline Variables & Categories & Controls \% & Cases & Total & $\begin{array}{l}\text { Global } \\
\text { p-value }\end{array}$ \\
\hline \multirow{6}{*}{ Age groups } & $\leq 39$ & 8.8 & 7.0 & $\begin{array}{ll}18 & 8.0 \\
\end{array}$ & \\
\hline & $40-49$ & $122 \quad 13.7$ & 14.5 & $205 \quad 14.0$ & \\
\hline & $50-59$ & $\begin{array}{ll}223 & 25.1 \\
\end{array}$ & 25.0 & $366 \quad 25.0$ & \\
\hline & $60-69$ & $\begin{array}{ll}243 & 27.3 \\
\end{array}$ & 27.1 & $398 \quad 27.2$ & \\
\hline & $70-79$ & $\begin{array}{ll}193 & 21.7 \\
\end{array}$ & $129 \quad 22.5$ & $322 \quad 22.0$ & \\
\hline & $80-89$ & $30 \quad 3.4$ & $22 \quad 3.8$ & $52 \quad 3.6$ & 0.87 \\
\hline \multirow{2}{*}{ Health system } & Public & $\begin{array}{ll}667 & 75.0 \\
\end{array}$ & $\begin{array}{ll}461 & 80.6 \\
\end{array}$ & 112877.2 & \\
\hline & Private & $222 \quad 25.0$ & $\begin{array}{ll}111 & 19.4 \\
\end{array}$ & 33322.8 & 0.01 \\
\hline \multirow{3}{*}{ Education years } & $\leq 6$ & $\begin{array}{ll}551 & 62.0 \\
\end{array}$ & 62.8 & $910 \quad 62.3$ & \\
\hline & $07-12$ & $\begin{array}{ll}223 & 25.1 \\
\end{array}$ & $\begin{array}{ll}142 & 24.8 \\
\end{array}$ & $365 \quad 25.0$ & \\
\hline & $\geq 13$ & $\begin{array}{ll}115 & 12.9 \\
\end{array}$ & $\begin{array}{ll}71 & 12.4 \\
\end{array}$ & $186 \quad 12.7$ & 0.94 \\
\hline \multirow{2}{*}{ Residence } & Urban & $\begin{array}{ll}805 & 90.5 \\
\end{array}$ & $\begin{array}{ll}498 & 87.1 \\
\end{array}$ & $1303 \quad 89.2$ & \\
\hline & Rural & $\begin{array}{ll}84 & 9.4 \\
\end{array}$ & 12.9 & $\begin{array}{ll}158 & 10.8 \\
\end{array}$ & 0.03 \\
\hline \multirow{3}{*}{$\begin{array}{l}\text { Body Mass Index } \\
\qquad\left(\mathrm{kg} / \mathrm{m}^{2}\right)\end{array}$} & $\leq 24.99$ & $\begin{array}{ll}389 & 43.8 \\
\end{array}$ & $238 \quad 41.6$ & $\begin{array}{ll}627 & 42.9 \\
\end{array}$ & \\
\hline & $25.0-29.99$ & $327 \quad 36.8$ & $210 \quad 36.7$ & $537 \quad 36.8$ & \\
\hline & $\geq 30.0$ & $\begin{array}{ll}173 & 19.5 \\
\end{array}$ & $\begin{array}{ll}124 & 21.7 \\
\end{array}$ & $297 \quad 20.3$ & 0.54 \\
\hline \multirow{2}{*}{ Fam.History of BC } & No & $\begin{array}{ll}811 & 91.2 \\
\end{array}$ & 78.7 & 126186.3 & \\
\hline & Yes & $\begin{array}{ll}78 & 8.8 \\
\end{array}$ & $\begin{array}{ll}122 & 21.3 \\
\end{array}$ & $200 \quad 13.7$ & $<0.001$ \\
\hline \multirow{2}{*}{ Menopausal status } & Pre & $182 \quad 20.5$ & $\begin{array}{ll}97 & 17.0 \\
\end{array}$ & $279 \quad 19.1$ & \\
\hline & Post & $\begin{array}{ll}707 & 79.5 \\
\end{array}$ & 83.0 & 118280.9 & 0.09 \\
\hline \multirow{4}{*}{ Age of menarche } & $\leq 11$ & $207 \quad 23.3$ & 24.1 & $345 \quad 23.6$ & \\
\hline & 12 & $273 \quad 30.7$ & $\begin{array}{ll}145 & 25.3 \\
\end{array}$ & $418 \quad 28.6$ & \\
\hline & 13 & $\begin{array}{ll}175 & 19.7 \\
\end{array}$ & $136 \quad 23.8$ & $311 \quad 21.3$ & \\
\hline & $\geq 14$ & $234 \quad 26.3$ & 26.7 & $387 \quad 26.5$ & 0.09 \\
\hline \multirow{3}{*}{$\mathrm{N}^{\mathrm{o}}$ of live births } & Nulliparous & $\begin{array}{ll}111 & 12.5 \\
\end{array}$ & 18.2 & $215 \quad 14.7$ & \\
\hline & $1-2$ & $\begin{array}{ll}394 & 44.3 \\
\end{array}$ & $252 \quad 44.1$ & $\begin{array}{ll}646 \quad 44.2 \\
\end{array}$ & \\
\hline & $\geq 3$ & $384 \quad 43.2$ & 37.8 & $600 \quad 41.1$ & 0.006 \\
\hline \multirow{3}{*}{ Age at $1^{\text {st }}$ live birth } & $\leq 20$ & $\begin{array}{ll}281 & 36.1 \\
\end{array}$ & 32.0 & $431 \quad 34.6$ & \\
\hline & $21-26$ & $\begin{array}{ll}304 & 39.1 \\
\end{array}$ & 37.0 & $477 \quad 38.3$ & \\
\hline & $\geq 27$ & $193 \quad 24.8$ & 31.0 & $338 \quad 27.1$ & 0.054 \\
\hline \multirow{3}{*}{$\begin{array}{l}\text { Breastfeeding time } \\
\quad \text { (total months) }\end{array}$} & $\leq 3$ & $283 \quad 31.8$ & 38.1 & $\begin{array}{ll}501 & 34.3 \\
\end{array}$ & \\
\hline & $1-4$ & $\begin{array}{ll}307 & 34.5 \\
\end{array}$ & 29.4 & $\begin{array}{ll}475 & 32.5\end{array}$ & \\
\hline & $\geq 16$ & $299 \quad 33.6$ & $186 \quad 32.5$ & $485 \quad 33.2$ & 0.03 \\
\hline Total patients & & $889 \quad 100.0$ & 572100.0 & 1461100.0 & \\
\hline
\end{tabular}


trained social workers interviewed cases and controls in the hospitals shortly after admittance and no proxy interviews were conducted.

\section{Private hospital}

The chosen medical institution was representative of the pre-paid system in Montevideo, with ca. 15.000 female affiliates (mostly inhabitants at the capital city) and showing a crude rate of $\mathrm{BC}$ of 267/100.000 due to its ca. 40 incident cases/year. During the study period 116 histologically verified cases of BC were collected. In the same time period 223 healthy women with a normal control mammography (Birads 1) (Feig, 1999), performed no longer than one year before the interview, were selected as controls ( 2 controls per case). One control and two cases had rejected the interview and three other cases $(0.9 \%)$ died during the study period, leading to a final number of 111 cases and 222 controls (response rates of $95.7 \%$ and $99.6 \%$ respectively). They were matched by age $( \pm$ 5 years) and residence (Montevideo and surrounding neighbourhoods), they were not hospitalized at the moment of the interview nor diagnosed with cancer. All women had ages $<85$, in an attempt to reduce a possible recall bias. Both cases and controls were women undergoing routine mammography testing and belonged to mid-to-high socio-economic strata. All interviews were conducted in the hospital and performed face-to-face by a trained nurse, who was blinded concerning major risk factors.

\section{Interviews and questionnaire}

A structured questionnaire was applied to all participants. The questionnaire included the following sections: (1) socio-demographic variables; (2) a section on occupation based on job titles and the duration of each activity; (3) history of cancer in first- and seconddegree relatives; (4) self-reported height and weight 5 years before the interview; (5) a tobacco smoking section (including age at starting, age of quitting, and average number of cigarettes smoked per day); (6) a history on alcohol drinking (including type of beverage, age at starting, age of quitting, and average amount of alcohol drunk per day); (7) a history of 'mate', tea and coffee drinking (age at starting, age of quitting, and average amount of the infusion drunk per day); (8) menstrual and reproductive events; and (9) a detailed food-frequency questionnaire (FFQ) on 64 items representative of the diet of the Uruguayan population, which asked about food consumption 5 years prior to diagnosis in cases and prior to the interview in controls. The FFQ was not validated, but was tested for reproducibility, having high correlations (Ronco et al., 2006). Furthermore, the FFQ allowed the total energy intake of each subject to be estimated. All dietary questions of our semi-quantitative questionnaire were open-ended.

Odds ratios (ORs) and $95 \%$ confidence intervals $(95 \%$ CI) were calculated by unconditional logistic regression (Breslow and Day, 1980). Potential confounders were included in the multivariate analysis. All equations included terms for hospital, residence, age, education, age at menarche, body mass index, number of childbirths, menopausal status, family history of BC in first and second degree relatives, smoking status, alcohol intake, total energy intake, and intakes of red meat, total fruits, total vegetables and tea. Likelihood-ratio tests were performed in order to explore possible heterogeneities in

Table 2. Selected population features according to their healthcare system

\begin{tabular}{|l|c|c|c|c|}
\hline \multicolumn{1}{|c|}{ Variable } & Units & $\begin{array}{c}\text { Public System } \\
\text { mean } \pm \text { SD* }\end{array}$ & $\begin{array}{c}\text { Private System } \\
\text { mean } \pm \text { SD* }\end{array}$ & p-value \\
\hline Age & years & $59.2 \pm 13.8$ & $60.5 \pm 9.9$ & 0.12 \\
\hline Education & years & $5.1 \pm 3.0$ & $12.4 \pm 4.1$ & $<0.001$ \\
\hline Urban status & \% of lifespan & $81.3 \pm 30.5$ & $98.5 \pm 6.3$ & $<0.001$ \\
\hline Height & cm & $160.1 \pm 6.2$ & $162.6 \pm 5.7$ & $<0.001$ \\
\hline Weight & Kg & $69.9 \pm 14.6$ & $63.9 \pm 8.8$ & $<0.001$ \\
\hline Body Mass Index & Kg/m & $27.3 \pm 5.5$ & $24.2 \pm 3.2$ & $<0.001$ \\
\hline Age at menarche & years & $12.7 \pm 1.6$ & $12.3 \pm 1.3$ & $<0.001$ \\
\hline Age at menopause & number & $47.0 \pm 5.5$ & $48.5 \pm 3.9$ & $<0.001$ \\
\hline Live births & years & $3.4 \pm 2.4$ & $2.1 \pm 0.9$ & $<0.001$ \\
\hline Age at 1st delivery & months & $23.1 \pm 5.7$ & $25.0 \pm 4.1$ & $<0.001$ \\
\hline Breastfeeding & servings/year & $226.2 \pm 149.7$ & $202.6 \pm 126.7$ & $<.01$ \\
\hline Red meat intake & servings/year & $54.7 \pm 46.5$ & $102.0 \pm 48.3$ & $<0.001$ \\
\hline Chicken intake & servings/year & $36.7 \pm 35.3$ & $80.4 \pm 39.7$ & $<0.001$ \\
\hline Fish intake & servings/year & $115.5 \pm 94.7$ & $40.8 \pm 41.2$ & $<0.001$ \\
\hline Stew intake & servings/year & $378.3 \pm 304.1$ & $1297.9 \pm 537.5$ & $<0.001$ \\
\hline Fruit intake & servings/year & $611.3 \pm 423.8$ & $1074.2 \pm 458.5$ & $<0.001$ \\
\hline Vegetables intake & cups/year & $33.5 \pm 106.8$ & $440.1 \pm 589.4$ & $<0.001$ \\
\hline Coffee intake & cups/year & $84.2 \pm 189.8$ & $421.0 \pm 304.8$ & $<0.001$ \\
\hline Tea intake & liters/day & $0.83 \pm 0.71$ & $0.73 \pm 0.63$ & 0.02 \\
\hline Mate intake & & & & $11.7 \pm 8.4$ \\
\hline
\end{tabular}

* SD $=$ Standard Deviation 
Table 3. Crude Odds Ratios (OR) of Selected Consumptions Linked to Lifestyle

\begin{tabular}{|c|c|c|c|c|c|}
\hline Variable & Categories & Controls /cases & Global p-value & OR* $(95 \% \mathrm{CI})$ & $\mathrm{p}$-value for trend \\
\hline Red meat & $\leq 112$ & $254 / 101$ & & & \\
\hline \multirow[t]{3}{*}{ (servings/year) } & 113-183 & $256 / 118$ & & & \\
\hline & $184-290$ & $228 / 138$ & & & \\
\hline & $\geq 291$ & $151 / 215$ & $<0.001$ & $3.58(2.62-4.88)$ & $<0.001$ \\
\hline Fruits & $\leq 218$ & $207 / 159$ & & & \\
\hline \multirow[t]{3}{*}{ (units/year) } & $219-365$ & $204 / 159$ & & & \\
\hline & $366-844$ & $236 / 130$ & & & \\
\hline & $\geq 845$ & $242 / 124$ & 0.006 & $0.67(0.49-0.90)$ & 0.001 \\
\hline Vegetables & $\leq 400$ & $190 / 173$ & & & \\
\hline \multirow[t]{3}{*}{ (servings/year) } & $401-620$ & $226 / 141$ & & & \\
\hline & $621-905$ & $245 / 118$ & & & \\
\hline & $\geq 906$ & $228 / 140$ & $<0.001$ & $0.67(0.50-0.90)$ & 0.003 \\
\hline Energy & $\leq 1625$ & $244 / 121$ & & & \\
\hline \multirow[t]{3}{*}{ (Kcal/day) } & 1626-1944 & $225 / 140$ & & & \\
\hline & $1945-2288$ & $215 / 150$ & & & \\
\hline & $\geq 2289$ & $205 / 161$ & 0.02 & $1.58(1.17-2.14)$ & 0.002 \\
\hline Coffee & None & $607 / 431$ & & & \\
\hline \multirow[t]{2}{*}{ (cups/year) } & $1-364$ & $105 / 60$ & & & \\
\hline & $\geq 365$ & $177 / 81$ & 0.009 & $0.64(0.48-0.86)$ & 0.002 \\
\hline Tea & None & $503 / 360$ & & & \\
\hline \multirow[t]{2}{*}{ (cups/year) } & $1-364$ & $90 / 70$ & & & \\
\hline & $\geq 365$ & $296 / 142$ & 0.002 & $0.67(0.53-0.85)$ & 0.002 \\
\hline Alcohol & Non drinker & $759 / 451$ & & & \\
\hline \multirow[t]{2}{*}{ Status } & Ex -drinker & $26 / 34$ & & & \\
\hline & Curr.drinker & $104 / 87$ & 0.002 & $1.41(1.03-1.91)$ & 0.007 \\
\hline Smoking & Non smoker & $659 / 409$ & & & \\
\hline \multirow[t]{2}{*}{ Status } & Ex -smoker & $59 / 54$ & & & \\
\hline & Curr.smoker & $171 / 109$ & 0.14 & $1.03(0.78-1.34)$ & 0.57 \\
\hline
\end{tabular}

*Crude OR (highest vs. lowest category)

the stratified analyses. All calculations were done with the software STATA (Release 10, StataCorp LP, College Station, TX, 2007).

\section{Results}

The distribution of cases and controls according to sociodemographic and reproductive factors is shown on Table 1. Although participants were not completely matched, the age distribution was adequate ( $p$-value= 0.87 ). More cases proceeded from rural areas than controls (12.93 vs. $9.45 \%$ respect.), but there were similarities regarding educational level ( $\mathrm{p}=0.94)$ and body mass index $(\mathrm{p}=0.54)$. As expected, family history of $\mathrm{BC}$, number of live births and breastfeeding time displayed significant differences and the age at first live birth was close to significance.

Table 2 compares the mean values with standard deviations of 20 selected items concerning the healthcare system of study participants. Unless age, all variables were significantly different. Women from the public system were less educated, lived a lesser part of their lifetime in urban areas and tended to be overweight. In addition, reproductive variables displayed a more protective profile. Conversely, dietary items showed the opposite except for the intake of stew. Regarding the studied hot infusions, high differences were found for coffee and tea intakes. Although the high prevalence of 'mate' intake in the whole population ( $82.6 \%$ of the sample, data not shown in this Table), its consumption was more intense among participants from the public system.

The comparison of selected items linked to lifestyle between cases and controls is shown on Table 3. Unless smoking status, the rest were significantly different. Crude ORs and their $95 \% \mathrm{CI}$ indicate that intakes of red meat, total calories and alcohol were positively associated to BC risk. On the other hand, total fruits, total vegetables, coffee and tea intakes were negatively associated to BC risk.

Table 4 is focused on the particular features of 'mate' intake. Adjusted ORs and their 95\% CI display a favorable situation for high exposure to this intake, compared to those categories of no/low intake. Current consumers showed a significant risk reduction of $\mathrm{BC}(\mathrm{OR}=0.65$, CI 0.47-0.90). A daily intake higher than 1 liter of the infusion was strongly protective $(\mathrm{OR}=0.40, \mathrm{CI} 0.26-0.57$, $\mathrm{p}$-value for trend $<0.001)$. Duration of the habit suggested the benefit of long-term 'mate' consumption $(\mathrm{OR}=0.66$, CI $0.44-0.99$, p-value for trend=0.04) and intensity of consumption (liters*years) also showed a strong inverse association for high consumers compared to non drinkers $(\mathrm{OR}=0.47$, CI 0.32-0.68, p-value for trend $<0.001)$. Only the estimates of daily intake remained unchanged when 
Table 4. Crude and Adjusted* Odds Ratios (OR) and 95\% Confidence Intervals (95\% CI) for 'Mate' consumption

\begin{tabular}{|c|c|c|c|c|c|}
\hline Variable & Categories & Controls/ Cases & $\begin{array}{c}\text { Crude OR } \\
(95 \% \text { CI) }\end{array}$ & $\begin{array}{l}\text { Adjusted OR } \\
(95 \% \mathrm{CI})\end{array}$ & $\mathrm{p}$-value for trend \\
\hline \multirow{3}{*}{ Mate status } & Non drinker & $146 / 108$ & Ref. & Ref. & \\
\hline & Ex-drinker & $59 / 44$ & $1.01(0.63-1.60)$ & $0.66(0.39-1.11)$ & \\
\hline & Current drinker & $684 / 420$ & $0.83(0.63-1.09)$ & $0.65(0.47-0.90)$ & 0.01 \\
\hline \multirow{4}{*}{$\begin{array}{l}\text { Amount } \\
\text { (liters/day) }\end{array}$} & $\leq 0.49$ & $189 / 147$ & Ref. & Ref. & \\
\hline & $0.50-0.99$ & $262 / 235$ & $1.15(0.87-1.52)$ & $0.86(0.62-1.17)$ & \\
\hline & 1.00 & $265 / 122$ & $0.59(0.44-0.80)$ & $0.54(0.39-0.76)$ & \\
\hline & $\geq 1.01$ & $173 / 68$ & $0.50(0.35-0.72)$ & $0.40(0.27-0.60)$ & $<0.001$ \\
\hline \multirow{4}{*}{$\begin{array}{l}\text { Duration } \\
\text { (years) }\end{array}$} & $\leq 9$ & $160 / 117$ & Ref. & Ref. & \\
\hline & $10--34$ & $259 / 139$ & $0.73(0.54-1.01)$ & $0.64(0.44-0.93)$ & \\
\hline & $35-50$ & $247 / 161$ & $0.89(0.65-1.22)$ & $0.69(0.48-0.98)$ & \\
\hline & $\geq 51$ & $223 / 155$ & $0.95(0.69-1.30)$ & $0.66(0.44-0.99)$ & 0.044 \\
\hline \multirow{4}{*}{$\begin{array}{l}\text { Intensity } \\
\text { (liters*years) }\end{array}$} & No intake & $146 / 108$ & Ref. & Ref. & \\
\hline & $0.10-24.5$ & $240 / 166$ & $0.92(0.67-1.26)$ & $0.74(0.51-1.07)$ & \\
\hline & $24.6-44.2$ & $248 / 173$ & $0.93(0.68-1.28)$ & $0.68(0.47-0.98)$ & \\
\hline & $\geq 44.3$ & $255 / 125$ & $0.66(0.47-0.91)$ & $0.50(0.34-0.73)$ & $<0.001$ \\
\hline
\end{tabular}

* Regression model included terms for: Health system (binary), residence (binary), age (categorical), education (continuous), age at menarche (categorical), menopausal status (binary), family history of breast cancer (binary), body mass index (categorical), number of live births (categorical), age at first delivery (continuous), breastfeeding months (categorical), smoking status (categorical), red meat intake (continuous), total fruit (categorical), total vegetables (categorical), dietary energy (categorical), tea intake (continuous) and alcohol intake (continuous).

Table 5. Odds Ratios (OR) of Mate Intake (Quartiles), Stratified for Categories of Selected Relevant Variables. Reference Category for Mate Intake is 0-0.49 Liters/Day

\begin{tabular}{|l|c|c|c|c|c|c|}
\hline \multirow{2}{*}{ Variable } & Categories & $\begin{array}{c}\text { II } \\
0.50-0.991 / \text { day }\end{array}$ & $\begin{array}{c}\text { III } \\
1.001 / \text { day }\end{array}$ & $\begin{array}{c}\text { IV } \\
\geq 1.01 \text { l/day }\end{array}$ & $\begin{array}{c}\text { p-value } \\
\text { for trend }\end{array}$ & $\begin{array}{c}\text { p-value } \\
\text { Heterogeneity }\end{array}$ \\
\hline \multirow{3}{*}{ Alcohol intake } & Never & $0.90(0.63-1.28)$ & $0.54(0.38-0.78)$ & $0.35(0.23-0.56)$ & $<0.001$ & \\
\cline { 2 - 7 } & Ever & $0.87(0.37-2.06)$ & $0.61(0.22-1.66)$ & $0.75(0.27-2.08)$ & 0.33 & 0.33 \\
\hline \multirow{3}{*}{ Tea intake (cups/yr) } & Never & $1.13(0.75-1.71)$ & $0.84(0.53-1.34)$ & $0.56(0.33-0.95)$ & 0.01 & \\
\cline { 2 - 8 } & $\leq 364$ & $0.79(0.28-2.17)$ & $0.57(0.17-1.97)$ & $0.33(0.08-1.31)$ & 0.10 & \\
\cline { 2 - 8 } & $\geq 365$ & $0.63(0.30-1.32)$ & $0.29(0.15-0.54)$ & $0.22(0.09-0.52)$ & $<0.001$ & 0.50 \\
\hline \multirow{2}{*}{ Red meat (serv/yr) } & $\leq 183$ & $0.86(0.54-1.37)$ & $0.74(0.46-1.19)$ & $0.67(0.37-1.20)$ & 0.13 & \\
\cline { 2 - 8 } & $\geq 184$ & $0.91(0.57-1.45)$ & $0.39(0.24-0.65)$ & $0.31(0.18-0.55)$ & $<0.001$ & 0.21 \\
\hline \multirow{2}{*}{ Fruits+veget. (serv/yr) } & $\leq 1039$ & $1.15(0.73-1.79)$ & $0.90(0.52-1.55)$ & $0.47(0.25-0.88)$ & 0.01 & \\
\cline { 2 - 8 } & $\geq 1040$ & $0.68(0.42-1.11)$ & $0.40(0.26-0.62)$ & $0.35(0.21-0.60)$ & $<0.001$ & 0.25 \\
\hline \multirow{2}{*}{\begin{tabular}{l} 
Energy kcal/day) \\
\cline { 2 - 8 }
\end{tabular}} & $\leq 1944$ & $1.10(0.70-1.74)$ & $1.11(0.68-1.83)$ & $0.90(0.49-1.65)$ & 0.88 & \\
\hline \multirow{2}{*}{ BMI status } & $\geq 1945$ & $0.71(0.44-1.14)$ & $0.30(0.18-0.48)$ & $0.23(0.13-0.40)$ & $<0.001$ & 0.008 \\
\hline \multirow{2}{*}{ FH of BC } & NW & $1.04(0.63-1.72)$ & $0.75(0.45-1.24)$ & $0.55(0.30-1.02)$ & 0.01 & \\
\hline \multirow{2}{*}{ Menop.status } & OW-OB & $0.73(0.48-1.12)$ & $0.40(0.25-0.64)$ & $0.29(0.17-0.51)$ & $<0.001$ & 0.17 \\
\hline \multirow{2}{*}{ Health syst. } & No & $0.87(0.62-1.23)$ & $0.53(0.37-0.77)$ & $0.45(0.29-0.69)$ & $<0.001$ & \\
\cline { 2 - 8 } & Pes & $0.90(0.32-2.54)$ & $0.67(0.25-1.82)$ & $0.15(0.04-0.63)$ & 0.02 & 0.43 \\
\hline
\end{tabular}

Regression model included terms for: Health system (binary), residence (binary), age (categorical), education (continuous), age at menarche (categorical), menopausal status (binary), family history of breast cancer (binary), body mass index (categorical), number of live births (categorical), age at first delivery (continuous), breastfeeding months (categorical), smoking status (categorical), red meat intake (continuous), total fruit (categorical), total vegetables (categorical), dietary energy (categorical), tea intake (continuous) and alcohol intake (g/day, continuous). Selected variables were excluded from the analyses when they were used for stratification; Abbreviations: BMI = Body Mass Index; NW = Normal weight $\left(\leq 24.99 \mathrm{~kg} / \mathrm{m}^{2}\right)$; OW-OB = Overweight-Obese $\left(\geq 25.00 \mathrm{~kg} / \mathrm{m}^{2}\right)$; FH of BC = Family history of breast cancer; Serv $/ \mathrm{yr}=$ servings/year; Menop. status = Menopausal status 
terms for 'mate' status, age at start and duration of habit were included in the multivariate model, whereas the other variables lost their association to BC risk (results not shown).

Finally, Table 5 shows the adjusted ORs for 'mate' intake, stratified for selected study variables. The inverse associations were stronger among high tea drinkers $(\mathrm{OR}=0.22)$, high energy intake $(\mathrm{OR}=0.23)$, overweightobese women $(\mathrm{OR}=0.29)$, high red meat consumers $(\mathrm{OR}=0.31)$, high fruits and vegetables consumers $(\mathrm{OR}=0.35)$ and alcohol abstainers $(\mathrm{OR}=0.35)$. In addition, mainly postmenopausal participants seemed to be protected $(\mathrm{OR}=0.36)$. Although it was a small subset, women with family history of BC displayed stronger inverse associations compared to those without it $(\mathrm{OR}=0.15 v s . \mathrm{OR}=0.45$, respectively). Interestingly, the likelihood-ratio test revealed significant heterogeneity only for the strata of energy intake $(\mathrm{p}=0.008)$.

\section{Discussion}

We have found inverse associations of 'mate' intake and the risk of $\mathrm{BC}$, considered from the viewpoint of consumer status (current consumers, $\mathrm{OR}=0.65, \mathrm{p}=0.01$ ), daily amount ( $>1$ liter/day, $\mathrm{OR}=0.40, \mathrm{p}<0.001)$, duration of habit $(>50$ years, $\mathrm{OR}=0.66, \mathrm{p}=0.04)$ and intensity of intake ( $>44.3$ liters*years, $\mathrm{OR}=0.50, \mathrm{p}<0.001$ ). In addition, only daily amount of 'mate' remained significantly associated when the other terms were included for adjustment in the regression model. These results differ from those ones emerging from the above quoted multi-site study (De Stefani et al., 2011a), where high intake of the beverage showed a negative and statistically not significant association to $\mathrm{BC}$ risk $(\mathrm{OR}=0.85$ for high intake $v s$. no intake, 95\%CI 0.67-1.09, p-value for trend=0.31). However, we think that the applied regression model probably explains in part those results. The former study had calculated the ORs using a polytomous multiple regression model including age, residence, education, smoking status, smoking cessation, smoking intensity, alcohol drinking and each 'mate' variable, having non 'mate' drinkers as reference category. On the other hand, for the present analysis we also took into account other covariates: hospital, family history of BC, body mass index, menstrual-reproductive variables (age at menarche, menopausal status, number of live births, age at first delivery, time of breastfeeding), total fruits, total vegetables, red meat, tea intake and total energy. These possible confounding variables are not a minor point.

The present study shows in Table 4 that crude risk for current 'mate' consumers is OR=0.83, 95\% CI 0.63-1.09, having non drinkers as reference category. This is almost identical to the above quoted OR for high intake $v s$. non consumers reported in the multi-site study. In other words, the former ORs appeared similar to our crude results: it seems likely that the adjustment for those variables was not enough to reduce the influence of important confounding factors of $\mathrm{BC}$ risk. The former multivariate model was probably very useful regarding several cancer sites afflicted by smoking and drinking, but was not enough for a specific, thorough analysis of BC.
Our results also face the existing controversy regarding 'mate' effects on cancer. According to a monograph published by the International Agency for Research on Cancer (IARC), hot 'mate' drinking has been considered as a $2 \mathrm{~A}$ agent, that is, a possible carcinogenic for humans (IARC, 1991). In fact, some studies found high levels of carcinogenic polycyclic aromatic hydrocarbons (PAH) (Gomes Zuin et al., 2005; Kamangar et al., 2008; Abnet, 2007; Golozar et al., 2012). A recent paper reported the presence of 8 PAHs in hot and cold 'mate' infusions (Thea et al., 2016). Among them, phenanthrene and benzo[a] pyrene $(\mathrm{BaP})$-considered as carcinogens to humans (IARC, 2010)- were found in both hot and cold 'mate', but the most recent paper also highlighted that none of the infusions exceeded the maximum level for BaP suggested by the World Health Organization for drinking water (700 ng/ml) (Thea et al., 2016). Besides, our group found dietary $\mathrm{BaP}$ intake as associated to an increase of $\mathrm{BC}$ risk (Ronco et al., 2011).

Regarding the links with BC, also Dimethylbenz[a] anthracene (DMBA) should be taken into account (Rengarajan et al., 2015), not only for causing BC in experimental rats, but also for being present in barbequed meat, tobacco smoke and overheated cooking oil, among other sources (Tiwari et al., 2014). DMBA is an important environmental contaminant that collaborates in generating several oxidative stress-mediated diseases, including cancer, but it has another relevant feature: it is a fat-soluble compound and because of this property it accumulates and persists in the adipose tissue of the mammary gland, therefore increasing the exposure of mammary epithelium to this chemical carcinogen (Ayyakkannu et al., 2014). Interestingly, DMBA, like BaP, is also an indirect-acting carcinogen, requiring metabolic activation to yield its ultimate carcinogenic form (Badal and Delgada, 2014), in particular an oxidation by CYP enzymes (Szaefer et al., 2014). Unlike the hot temperature of the infusion -accepted as a risk factor for cancers of the upper aerodigestive tract (De Stefani et al., 1988; 1990; Lubin et al., 2014)-, the quoted components could be partially responsible of the association of 'mate' with cancer in organs which have no direct contact with the beverage: lung (De Stefani et al., 1996), bladder (De Stefani et al., 1991; 2007), kidney (De Stefani et al., 1998b), prostate (De Stefani et al., 2011b) and also cervix uteri (De Stefani et al., 2011a).

On the other hand, nevertheless, hot 'mate' infusion appears within a long list of products which have priority to be reassessed by the IARC (IARC, 2014), since it has been extensively studied (Heck and de Mejia, 2007; Loria et al., 2009) and basic research has demonstrated the presence of several compounds which have antioxidant properties (polyphenols, flavonoids), among other ones as chlorogenic acids (Jaiswal et al., 2010) and methylxantines (caffeine, teobromin) (Heck and de Mejia, 2007; Bracesco et al., 2011). Moreover, 'mate' infusion has shown comparable oxygen radical scavenger activity as ascorbate, glutathione and cysteine (Coppes et al., 2014). Furthermore, a recent experimental study in mice showed preventive effects of 'mate' against mammary carcinogenesis induced by DMBA and dimethylhydrazine (Zapaterini et al., 2010). Despite this evidence, we must 
recognize that some studies failed to report a decreased risk associated with this beverage (Heck and de Mejia, 2007; Loria et al., 2009; World Cancer Research Fund, 2007).

The protective effects of 'mate' described in the present study appear to be stronger among strata of tea drinkers and high plant foods eaters. According to recent reviews, although high polyphenols contents of different tea types have been described (Wang et al., 2015), lack of association tends to prevail in the literature regarding tea intake and the risk of BC (Gao et al., 2013; Wu et al., 2013). Nevertheless, potential benefits could be linked to an additional antioxidant load coming from different sources, and this was suggested regarding tea consumption, where the OR of high 'mate' drinkers goes from a general 0.40 (shown in Table 4) to 0.22 for the strata of highest tea drinkers (shown in Table 5), even though reference categories are not identical. Additional analyses considering non drinkers as reference category did not change the estimates for an intake higher than 1 liter/day $(\mathrm{OR}=0.40,95 \% \mathrm{CI} 0.26-0.62$, results not shown in Tables). Furthermore, an $\mathrm{OR}=0.67$ for high tea drinkers and an $\mathrm{OR}=0.40$ for high 'mate' drinkers suggest that the estimated $\mathrm{OR}=0.22$ for both high intakes combined could be an additive protection.

An inverse association was apparent mainly for postmenopausal women, although heterogeneity test was not significant between strata $(\mathrm{p}=0.62)$. Whether the difference is only a matter of time for the antioxidant effects or there is indeed a relation to hormonal status, is something we cannot disentangle at this moment due to its own complexity. In support to this statement, we must take into account that strong negative associations of 'mate' were also found in women with high dietary energy intake (heterogeneity test $\mathrm{p}<0.01$ ) and high BMI: both are linked to higher oxidative stress, but the latter also represents more intense aromatization of androgens into active estrogens taking place within the adipose tissue, mainly in postmenopausal women. Consequently, obesity and certain dietary styles, among other factors, increase the $\mathrm{BC}$ risk by reduction of 2/16 $\alpha$-hydroxyestrogens ratio (Muti et al., 2000; Ronco et al., 2010). Moreover, according to the above quoted recent studies on $\mathrm{PAH}$, a potential antioxidant activity of 'mate' reducing or partially blocking the metabolic activation of $\mathrm{BaP}$ and DMBA could not be ruled out. In this sense, the potential carcinogenic compounds which have been found in 'mate' infusion could be counterbalanced and also overcome by its own antioxidant compounds.

Anyway, we believe that the evidence suggests a more protective effect along time, perhaps enhancing existing biological differences between $\mathrm{BC}$ in younger and in older women. It is not new that $\mathrm{BC}$ is different in both subgroups: we have already recognized that premenopausal women are in a disadvantageous situation from a dietary viewpoint compared to postmenopausal ones, mainly because of a relative lack of protective items (Ronco and De Stefani 2012; 2013; Ronco et al., 2012; 2013; 2015). Combining food and nutrients patterns, the latter communication (Ronco et al., 2015) reported lack of association for Carotenoids, Fruit-based, Prudent and
Total fruits dietary patterns among premenopausal women, whereas these patterns showed a protective effect among postmenopausal ones. Something probably playing a role of common link among the quoted patterns is their antioxidant load. Since 'mate' intake was not taken into account in such study, the facts suggest us that regarding $\mathrm{BC}$ risk, those other dietary items with antioxidant capabilities apparently do not work either in favour of younger women.

As other case-control studies, our work has limitations and strengths. Among the limitations we recognize the lack of validation of the questionnaire, although the instrument was tested for reproducibility. Also, the control population displayed different profiles: hospitalized participants were recruited from the public system and non hospitalized ones from the private system. All of them shared a common condition, which was the absence of any cancer. However, the latter subgroup had also documented absence of any breast pathology. Therefore, having selected as controls women with normal mammograms and not only without cancer, if benign breast diseases had any association with the analyzed dietary items we reduced at least in part the possibility of biasing results due to this. Also to be mentioned as strength, the study population includes subsets of both existing healthcare systems, proceeding from the capital city as well as the rest of the country, and times of data collection were coincident. Although age matching was not perfect for the public hospitals subset, the whole resulting distribution was reasonable. Finally, a high participation was achieved (globally $97.1 \%$ of patients under the proposed age limits), reducing the likelihood of selection bias. Albeit it is not possible to avoid completely any bias, including recall bias, we think that results were not chance findings.

In conclusion, after analyzing a population sample comprised by women belonging to both healthcare systems existing in the country, we found evidence of a protective effect of 'mate' drinking on the risk of BC. This effect displayed linear trends for daily amount, duration of habit and intensity of intake, being in appearance mainly protective for postmenopausal women. The need of additional studies is evident, mainly to elucidate possible links to hormonal features which are currently taken into account at diagnostic stages and for therapeutical purposes, and this is a task for the close future.

\section{References}

Abnet CC (2007). Carcinogenic food contaminants. Cancer Invest, 25, 189-96.

Ayyakkannu P, Elumalai N, Palanivelu S, Panchanadham S (2014). Shemamruthaa, herbal formulation modulates xenobiotic metabolizing enzymes and energy metabolism in 7,12-Dimethylbenz [a] anthracene-induced breast cancer in rats. $J$ Biochem Tech, 5, 801-7.

Badal S, Delgada R (2014). Role of the modulation of CYP1A1 expression and activity in chemoprevention. J Appl Toxicol, 34, 743-53.

Barrios E, Garau M, Alonso R, Musetti C (2014). IV Atlas of Cancer Incidence in Uruguay. Comision Honoraria de Lucha Contra el Cancer, Montevideo, Uruguay. (in Spanish)

Bhoo-Pathy N, Peeters PH, Uiterwaal CS, et al (2015). Coffee 
and tea consumption and risk of pre- and postmenopausal breast cancer in the European Prospective Investigation into Cancer and Nutrition (EPIC) cohort study. Breast Cancer Res, 17, 15.

Bracesco N, Sanchez AG, Contreras V, et al (2011). Recent advances on Ilex paraguariensis research: minireview. $J$ Ethnopharmacol, 136, 378-84.

Breslow NE, Day NE (1980). Statistical methods in cancer research: Volume 1. The analysis of case-control studies. International Agency Res Cancer Sci Pub, 32, Lyon, France.

Castellsague X, Muñoz N, De Stefani E, et al (2000). Influence of mate drinking, hot beverages and diet on esophageal cancer risk in South America. Int J Cancer, 88, 658-64.

Comision Honoraria de Lucha Contra el Cancer (1993). Knowledge, beliefs, attitudes and practices related to cancer: population survey. Technical cooperation PNUD/ BID. Comision Honoraria de Lucha Contra el Cancer, Montevideo, Uruguay.

Coppes Z, Escardo C, Pavlisko A, Leonard SS (2014). Antioxidant properties of Yerba Mate tea and its inhibition of radical DNA damage, and comparison with other types of tea. Proceedings of the VI South American Congress on Yerba Mate, Montevideo. Abst, 150, 194.

De Stefani E, Correa P, Oreggia F, et al (1988). Black tobacco, wine and mate in oropharyngeal cancer. A case-control study from Uruguay. Rev Epidemiol Sante Publique, 36, 389-94.

De Stefani E, Muñoz N, Esteve J, et al (1990). Mate drinking, alcohol, tobacco, diet, and esophageal cancer in Uruguay. Cancer Res, 50, 426-31.

De Stefani E, Correa P, Fierro L, et al D (1991). Black tobacco, mate, and bladder cancer. A case-control study from Uruguay. Cancer, 67, 536-40.

De Stefani E, Fierro L, Correa P, et al (1996). Mate drinking and risk of lung cancer in males. A case control study from Uruguay. Cancer Epidemiol Biomarkers Prev, 5, 515-9.

De Stefani E, Ronco AL, Mendilaharsu M, et al (1997a). Meat intake, heterocyclic amines, and risk of breast cancer: a casecontrol study in Uruguay. Cancer Epidemiol Biomarkers Prev, 6, 573-81.

De Stefani E, Correa P, Ronco AL, et al (1997b). Dietary fiber and risk of breast cancer. A case-control study in Uruguay. Nutr Cancer, 28, 14-9.

De Stefani E, Deneo-Pellegrini H, Mendilaharsu M, Ronco AL (1998a). Essential fatty acids and breast cancer: a casecontrol study in Uruguay. Int J Cancer, 76, 491-4.

De Stefani E, Fierro L, Mendilaharsu M, et al (1998b). Meat intake, "mate" drinking and renal cell cancer in Uruguay. A case-control study. Br J Cancer, 78, 1239-43.

De Stefani E, Boffetta P, Deneo-Pellegrini H, et al (2007). Nonalcoholic beverages and risk of bladder cancer in Uruguay. BMC Cancer, 7, 57.

De Stefani E, Moore M, Aune D, et al (2011a). Mate Consumption and Risk of Cancer: a Multi-site Case-Control Study in Uruguay. Asian Pac J Cancer Prev, 12, 1089-93.

De Stefani E, Deneo-Pellegrini H, Ronco AL, et al (2011b). Alcohol Drinking, Non-alcoholic Beverages and Risk of Advanced Prostate Cancer among Uruguayan Men.J Cancer Sci Ther, 1, 1-6

Deneo-Pellegrini H, De Stefani E, Boffetta P, et al (2013). Mate consumption and risk of oral cancer: Case-control study in Uruguay. Head Neck, 35, 1091-5.

Feig SA (1999). Role and evaluation of mammography and other imaging methods for breast cancer detection, diagnosis, and staging. Semin Nucl Med, 29, 3-15.

Ferlay J, Soerjomataram I, Ervik M, et al (2013). GLOBOCAN 2012 v1.0, Cancer Incidence and Mortality Worldwide: IARC CancerBase No. 11 [Internet]. Lyon, France:
International Agency for Research on Cancer.

Gao Y, Huang YB, Liu XO, et al (2013). Tea consumption, alcohol drinking and physical activity associations with breast cancer risk among chinese females: a systematic review and meta-analysis. Asian Pac J Cancer Prev, 14, 7543-50.

Gierach GL, Freedman ND, Andaya A, et al (2012). Coffee intake and breast cancer risk in the NIH-AARP diet and health study cohort. Int J Cancer, 131, 452-60.

Golozar A, Fagundes RB, Etemadi A, et al (2012). Significant variation in the concentration of carcinogenic polycyclic aromatic hydrocarbons in yerba mate samples by brand, batch, and processing method. Environ Sci Technol, 46, 13488-93.

Gomes Zuin V, Montero L, Bauer C, Popp P (2005). Stir bar sorptive extraction and high-performance liquid chromatography-fluorescence detection for the determination of polycyclic aromatic hydrocarbons in Mate teas. $J$ Chromatog A, 1091, 2-10.

Heck CI, de Mejia EG (2007). Yerba Mate Tea (Ilex paraguariensis): a comprehensive review on chemistry, health implications, and technological considerations. $J$ Food Sci, 72, 138-51.

IARC Monographs on the Evaluation of Carcinogenic Risks to Humans (1991). Volume 51. Coffee, Tea, Mate, methylxanthines and methylglyoxal. IARC, Lyon, France, pp 273-87.

IARC Monographs on the Evaluation of Carcinogenic Risks to Humans (2010). Volume 92. Some non-heterocyclic polycyclic aromatic hydrocarbons and some related exposures. IARC, Lyon, France, 92, 1-853.

IARC Monographs on the Evaluation of carcinogenic risks to humans (2014). Report of the Advisory Group to Recommend Priorities for IARC Monographs during 20152019, Lyon.

Jaiswal R, Sovdat T, Vivan F, Kuhnert N (2010). Profiling and characterization by LC-MSn of the chlorogenic acids and hydroxycinnamoylshikimate esters in mate (ilex paraguariensis). J Agricult Food Chem, 58, 5471-84.

Jiang W, Wu Y, Jiang X (2013). Coffee and caffeine intake and breast cancer risk: an updated dose-response meta-analysis of 37 published studies. Gynecol Oncol, 129, 620-9.

Kamangar F, Schantz MM, Abnet CC, et al (2008). High levels of carcinogenic polycyclic aromatic hydrocarbons in mate drinks. Cancer Epidemiol Biomarkers Prev, 17, 1262-8.

Loria D, Barrios E, Zanetti R (2009). Cancer and yerba mate consumption: a review of possible associations. Pan Am Public Health J, 25, 530-9.

Lubin JH, De Stefani E, Abnet CC, et al (2014). Mate drinking and esophageal squamous cell carcinoma in south america: pooled results from two large multicenter case-control studies. Cancer Epidemiol Biomarkers Prev, 23, 107-16.

Muti P, Bradlow HL, Micheli A, et al (2000). Estrogen metabolism and risk of breast cancer: a prospective study of the 2:16a-hydroxyestrone ratio in premenopausal and postmenopausal women. Epidemiol, 11, 635-40.

Nie XC, Dong DS, Bai Y, Xia P (2014). Meta-analysis of black tea consumption and breast cancer risk: update 2013. Nutr Cancer, 66, 1009-14.

Parkin DM, Whelan SL, Ferlay J, et al (eds) (2002). Cancer incidence in five continents, vol. VIII. IARC Scientific Publications $\mathrm{N}^{\mathrm{o}}$ 155, International Agency for Research on Cancer, Lyon.

Rengarajan T, Rajendran P, Nandakumar N, et al (2015). Exposure to polycyclic aromatic hydrocarbons with special focus on cancer. Asian Pac J Trop Biomed, 5, 182-9.

Ronco AL, De Stefani E, Mendilaharsu M, Deneo-Pellegrini H 
(1996). Meat, fat and the risk of breast cancer: a case-control study from Uruguay. Int J Cancer, 65, 328-31.

Ronco AL, De Stefani E, Boffetta P, et al (1999). Vegetables, fruits, and related nutrients and risk of breast cancer: a case control study in Uruguay. Nutr Cancer, 35, 111-9.

Ronco AL, Barrios E, Fierro L, et al (2004). Risk factors for oesophageal cancer in non smokers and non drinkers. Braz J Epidemiol, 7, 383-91.

Ronco AL, De Stefani E, Boffetta P, et al (2006). Food patterns and risk of breast cancer: A factor analysis study in Uruguay. Int J Cancer, 119, 1672-8.

Ronco AL, Mendoza B, Varas X, et al (2008). Somatotype and risk of breast cancer: a case-control study in Uruguay. Braz J Epidemiol, 11, 215-27.

Ronco AL, Boeing H, De Stefani E, et al (2009). A case-control study on fat- to-muscle ratio and risk of breast cancer. Nutr Cancer, 61, 466-74.

Ronco AL, De Stefani E, Stoll M (2010a). Hormonal and metabolic modulation through nutrition: towards a primary prevention of breast cancer. Breast, 19, 322-32.

Ronco AL, De Stefani E, Aune D, et al (2010b). Nutrient patterns and risk of breast cancer in Uruguay. Asian Pac J Cancer Prev, 11, 519-24.

Ronco AL, De Stefani E, Correa P, et al (2011). Dietary benzo[a] pyrene, alcohol drinking, and the risk of breast cancer: a case-control study in Uruguay. Asian Pac J Cancer Prev, 12, 1463-7.

Ronco AL, De Stefani E (eds) (2012). Nutritional Epidemiology of Breast Cancer. Springer Publishers, Dordrecht.

Ronco AL, De Stefani E, Deneo-Pellegrini H (2012). Risk factors of premenopausal Breast Cancer: A Case-Control Study in Uruguay. Asian Pac J Cancer Prev, 13, 2879-86.

Ronco AL, De Stefani E (2013). Nutrition and breast cancer in pre- and post-menopausal women in uruguay. in: collins CJ, Ross Watson R, Preedy VR (eds.) handbook of nutrition and diet in menopause. humana press, New York, 281-92.

Ronco AL, De Stefani E, Deneo-Pellegrini H (2013). Body composition, somatotype and risk of premenopausal breast cancer: a case-control study in Uruguay. J Cancer Res Treat, 1, 77-86

Ronco AL, Mendoza B, Abbona E, De Stefani E (2015). Dietary patterns and risk of breast cancer: a factor analysis of foods and nutrients. VI Ibero American Congress of Nutrition, September 8-11th, Montevideo, Uruguay (in Spanish)

Sewram V, De Stefani E, Brennan P, Boffetta P (2003). Mate consumption and the risk of squamous cell esophageal cancer in Uruguay. Cancer Epidemiol Biomarkers Prev, 12, 508-13.

Szaefer H, Krajka-Kuźniak V, Ignatowicz E, et al (2014) The effect of cloudy apple juice on hepatic and mammary gland phase I and II enzymes induced by DMBA in female Sprague-Dawley rats. Drug Chem Toxicol, 37, 472-9.

Thea AE, Ferreira D, Brumovsky LA, Schmalko ME (2016). Polycyclic aromatic hydrocarbons (PAHs) in yerba mate (Ilex paraguariensis St. Hil) traditional infusions (mate and terere). Food Control, 60, 215-20.

Tiwari P, Sahay S, Pandey M, et al (2014). Combinatorial chemopreventive effect of butyric acid, nicotinamide and calcium glucarate against the 7,12-dimethylbenz(a) anthracene induced mouse skin tumorigenesis attained by enhancing the induction of intrinsic apoptotic events. Chem Biol Interact, 226, 1-11.

Vassallo A, Correa P, De Stefani E, et al (1985). Esophageal cancer in Uruguay: a case-control study. J Natl Cancer Inst $\mathbf{7 5}, 1005-9$.

Wang J, Tang L, Wang J-S (2015). Biomarkers of Dietary Polyphenols in Cancer Studies: Current Evidence and Beyond. Oxid Med Cell Longevity, 732302
World Cancer Research Fund/American Institute for Cancer Research (2007). Food, nutrition, physical activity, and the prevention of cancer: a global perspective. Washington DC, AICR, 148-56.

Wu Y, Zhang D, Kang S (2013). Black tea, green tea and risk of breast cancer: an update. Springer Plus, 2, 240.

Zapaterini JR, Bidinotto LT, Rodrigues MAM, Barbisan LF (2010). Chemopreventive effects of mate against mouse mammary and colon carcinogenesis. Hum Exp Toxicol, 29, $175-85$. 